\title{
The Role of Interferon Therapy in Patients With Hepatocellular Carcinoma
}

\section{Mark W. Russo, MD, MPH}

\author{
Corresponding author \\ Mark W. Russo, MD, MPH \\ Division of Transplantation, Carolinas Medical Center, Annex Building, \\ Third Floor, 1000 Blythe Boulevard, Charlotte, NC 28203, USA. \\ E-mail: Mark.Russo@carolinas.org \\ Current Hepatitis Reports 2009, 8:175-181 \\ Current Medicine Group LLC ISSN 1540-3416 \\ Copyright @ 2009 by Current Medicine Group LLC
}

Interferon (IFN) not only may have antiviral properties against hepatitis $\mathrm{C}$, but also may reduce the risk of hepatocellular carcinoma (HCC) through anticarcinogenic properties or indirectly by antifibrotic effects. Because patients with chronic hepatitis $\mathrm{C}$ and cirrhosis are at risk for HCC, IFN was used to prevent or treat HCC in patients with hepatitis C. Studies demonstrate that the risk of HCC in hepatitis $\mathrm{C}$ patients who are sustained viral responders is substantially reduced but not eliminated. The Hepatitis C Antiviral Long-Term Treatment Against Cirrhosis trial demonstrated that maintenance therapy with IFN does not reduce the risk of HCC in patients with bridging fibrosis or cirrhosis. Other studies suggest the risk of HCC is reduced with IFN maintenance therapy in older patients or in patients whose $\alpha$-fetoprotein levels decline. A randomized clinical trial demonstrated IFN therapy is not effective against HCC. Few studies suggest IFN may reduce the risk of recurrent $\mathrm{HCC}$ or reduce tumor burden after ablation or resection. Larger trials are needed to determine if IFN can prevent tumor recurrence after resection or locoregional therapy in patients with hepatitis $\mathrm{C}$ cirrhosis and HCC.

\section{Introduction}

The intermediate goal of interferon (IFN)-based therapy for hepatitis $\mathrm{C}$ is to achieve a sustained viral response (SVR). The long-term goal is to reduce or eliminate complications from cirrhosis, including hepatocellular carcinoma (HCC). Although SVR rates have improved significantly, data are emerging on the impact of IFNbased therapy on reducing complications from cirrhosis, including HCC. Treatment of HCC is challenging and for the most part was limited to resection, locoregional therapy, or liver transplant. Only recently-with the development of sorafenib-was systemic therapy proven effective in treating HCC [1].

Although used for more than two decades to treat hepatitis $\mathrm{C}$, the role of IFN in the prevention or treatment of HCC has been elusive. IFN is used 1) to achieve SVR with the goal of reducing or eliminating complications from chronic liver disease, including HCC, 2) as maintenance therapy in patients with bridging fibrosis and cirrhosis, 3) as chemotherapy to treat HCC, and 4) to prevent recurrence after resection or ablative therapies. This article summarizes the role of IFN in preventing or treating HCC.

\section{Carcinogenic Properties of Hepatitis C and} Anticarcinogenic Properties of $\alpha$-IFN

Hepatitis $\mathrm{C}$ may have a direct or indirect role in carcinogenesis. Hepatitis $\mathrm{C}$ may indirectly promote carcinogenesis through fibrosis. Patients with advanced fibrosis or cirrhosis are at increased risk for carcinogenesis because chromosomal alterations that occur in fibrotic tissue are associated with tumor formation $[2,3]$. In cirrhotic hepatocytes, telomere shortening may lead to chromosome uncapping, which induces DNA damage and chromosomal fusion [2]. Cells with fused chromosomes that enter the cell cycle may develop translocations and chromosomal instability, which may lead to carcinogenesis.

Hepatitis C may promote carcinogenesis through chronic inflammation or stimulation of hepatic stellate cells, with subsequent fibrosis. Chronic liver inflammation is associated with a shift in signaling from transforming growth factor (TGF) $\beta$, resulting in a change from tumor suppression to fibrosis and carcinogenesis [4]. Proliferative changes in hepatic tissue related to ongoing inflammation from hepatitis are associated with repeated cycles of cell death and regeneration [3]. Repeated cell cycles are associated with accumulation of mutations that may transform hepatocytes to malignant cells through a multistage process. However, chronic inflammation by itself does not seem to promote carcinogenesis, because patients who have persistent chronic liver inflammation from autoimmune liver disease rarely develop HCC. Hepatitis C nonstructural protein genes promote fibrosis partly through inducing TGF $\beta$ and activating hepatic stellate cells [5]. This finding

The online version of the original article can be found at http://dx.doi.org/10.1007/s11901-010-0075-x. This paper contained errors on texts, tables and layout. The corrected version of this paper is republished here in its entirely. 
was demonstrated in cell culture systems when sera from hepatitis $\mathrm{C}$ patients stimulate hepatic stellate cell proliferation, which subsequently leads to fibrosis [5]. Hepatitis C core protein may promote carcinogenesis. In a transgenic mouse model, hepatitis $\mathrm{C}$ core protein led to the development of HCC without the genetic aberrations typically seen in carcinogenesis, such as in colon cancer [6].

IFN may reduce the risk of hepatocellular carcinoma through antifibrotic effects or antineoplastic properties. Antineoplastic properties of IFN- $\alpha$ may be demonstrated through their effects on hepatitis $\mathrm{C}$-induced fibrinogenesis and hepatic stellate cells. IFN- $\alpha$ with ribavirin decreases hepatitis $\mathrm{C}$-stimulated hepatic stellate cell proliferation by $50 \%$ [7]. IFN may promote fibrinolysis by inhibiting tissue inhibitor of metalloproteinase (an inhibitor of fibrin degradation) or promoting hepatic stellate cell death. In a rat model of carbon tetrachloride-induced liver fibrosis, significantly lower levels of tissue inhibitor of metalloproteinase were found in rats treated with pegylated IFN $-\alpha-2 b$ compared with untreated rats $(P<0.05)$ [8]. Hepatic stellate cell apoptosis was higher in the animals administered pegylated IFN compared with the control group $(P<0.01)$.

The antineoplastic properties of IFN are partly mediated through inhibition of angiogenesis and promotion of tumor cell apoptosis. In murine models of HCC, IFN- $\alpha$ decreases serum vascular endothelial growth factor and microvessel density, which is associated with a significantly lower rate of lung metastases and recurrent HCC after resection $(P<0.05)$ [9]. IFN may inhibit tumorigenesis through antiangiogenesis by down-regulating vascular endothelial growth factor. A murine model of HCC demonstrates that animals administered IFN- $\alpha-2 b$ had decreased gene expression of vascular endothelial growth factor and cyclooxygenase-2 [10]. Apoptosis was greater in the tumor cells of mice treated with IFN compared with controls $(P<$ 0.01). Thus, IFN inhibited tumor growth not only through antiangiogenesis, but also through increased apoptosis in tumor cells. Other studies in tumor cell lines demonstrate the apoptotic effects of IFN- $\alpha$ and 5-fluorouracil are mediated partly through the Fas/FasL pathway [11].

In summary, animal studies and studies in tumor cell lines demonstrate antineoplastic effects of IFN on HCC through multiple mechanisms. These effects are mediated through inhibiting fibrosis production, hepatic stellate cell activation, inhibition of tumor angiogenesis, and promotion of tumor apoptosis.

\section{HCC in Patients Treated With IFN-based Therapy}

The risk of HCC in hepatitis C patients who achieve SVR is markedly reduced, but patients remain at risk for HCC, especially those with bridging fibrosis or cirrhosis [12]. Although eradication of hepatitis $\mathrm{C}$ virus $(\mathrm{HCV})$ in the serum 6 months after therapy is terminated serves as a surrogate to eradicating virus in the liver, studies show that HCV RNA persists in the liver and peripheral blood mononuclear cells in some patients with SVR $[13,14]$. A study in nine patients with SVR found that peripheral blood mononuclear cells from three individuals elicited productive infection in vitro [13]. The association of persistent viral RNA in peripheral blood mononuclear cells or in the liver and the risk of HCC is unknown.

Studies demonstrate that the risk of HCC in sustained responders is reduced compared with nonresponders [1519]. In a multicenter, retrospective study of 479 patients with hepatitis $\mathrm{C}$ who were treated with IFN or pegylated IFN with or without ribavirin, $142(29.6 \%)$ subjects had SVR [15]. In sustained responders, the HR for HCC was 0.46 (95\% CI, $0.12-1.70 ; P=0.25)$ compared with those who did not have SVR [15]. All patients in the study had bridging fibrosis or cirrhosis, and the median follow-up was 2.1 years. An analysis of 1124 patients with hepatitis C reported that $3.5 \%$ of those with SVR developed HCC after a median follow-up of 5.8 years [16]. The patients with SVR who developed HCC were more likely male, older, and had more advanced fibrosis compared with patients with SVR who did not develop HCC. Three of the 13 patients with SVR who developed HCC had mild fibrosis. No significant difference was seen in the rate of HCC in the partial response group compared with the nonresponders. In an analysis of 1191 patients with hepatitis $C$ who were treated with IFN, and 452 untreated patients, estimates of HCC rates after 5 and 10 years of treatment with IFN were $2.1 \%$ and $7.6 \%$, compared with $4.8 \%$ and $12.4 \%$ without treatment [17]. The risk of HCC was lowest in patients with normal alanine transaminase (ALT) values, with or without HCV RNA clearance (HR, $0.32 ; P=0.012)$. Thus, HCC occurs in hepatitis C patients who have achieved SVR, but almost all of these patients had bridging fibrosis and cirrhosis. A meta-analysis of 11 studies involving 2178 patients found that hepatocellular carcinoma was 3.7 times more common in nonsustained responders compared with sustained responders (OR, 3.7; 95\% CI, 1.7-7.8) [12]. Even patients who did not achieve SVR seemed to benefit from IFN, because the risk of HCC in untreated patients was 2.7-fold higher compared with patients treated with IFN (OR, 2.7; 95\% CI, 1.9-3.9) [12].

Among patients who develop HCC after SVR, HCV RNA is found in hepatic tissue [20]. Microscopic pathologic features of HCC are similar between patients who have achieved SVR and nonresponders. At the molecular level, however, alterations in mitochondrial DNA and methylation status are less frequent in HCC from sustained responders than HCC from patients with chronic hepatitis C [14]. The implications of these differences in molecular alterations in HCC from sustained responders and patients with chronic hepatitis $\mathrm{C}$ are unknown.

Although studies consistently demonstrate a significant reduction in risk of HCC among sustained responders, HCC occurs in patients with SVR. Thus, patients with SVR and bridging fibrosis or cirrhosis may warrant ongoing surveillance for HCC, particularly patients who are older, male, and have elevated ALT levels. 


\begin{tabular}{|c|c|c|c|c|}
\hline Study & Treatment groups, $n$ & Design & Results & Comments \\
\hline Nishiguchi et al. [22] & $\begin{array}{l}90 \text { patients received } \\
\text { IFN- } \alpha ; 45 \text { untreated } \\
\text { controls }\end{array}$ & $\begin{array}{l}\text { Randomized trial: IFN, } 6 \\
\text { MU TIW, administered } \\
\text { for } 12-24 \text { wk for } 2-7 \text { y }\end{array}$ & $\begin{array}{l}\text { Rate of HCC in IFN group, } \\
4 \% \text {; in control group, } \\
38 \% ; P=0.002\end{array}$ & - \\
\hline Shiffman et al. [21] & $\begin{array}{l}27 \text { patients received } \\
\text { IFN- } \alpha-2 b ; 26 \\
\text { patients received } \\
\text { no treatment }\end{array}$ & $\begin{array}{l}\text { Randomized trial: IFN, } \\
3 \text { MU TIW, for } 24 \text { mo; } \\
\text { liver biopsies } 1 \text { and } 2 \text { y } \\
\text { after IFN }\end{array}$ & $\begin{array}{l}\text { Decrease in fibrosis and } \\
\text { inflammation on liver } \\
\text { biopsy in IFN group but } \\
\text { not in control group }\end{array}$ & $\begin{array}{l}\text { Rate of HCC, liver } \\
\text { complications not } \\
\text { reported }\end{array}$ \\
\hline Arase et al. [25] & $\begin{array}{l}120 \text { received IFN- } \alpha \text {, } \\
2-3 \text { times weekly } \\
\text { over median } 2.4 \text { y; } \\
240 \text { patients treated } \\
\text { with herbal products } \\
\text { served as historical } \\
\text { control group }\end{array}$ & $\begin{array}{l}\text { Prospective, nonran- } \\
\text { domized study in } \\
\text { patients with hepatitis } \\
\mathrm{C} \text { cirrhosis age } 60 \mathrm{y} \\
\text { and older, ALT > } 1.5 \\
\text { times ULN, median } \\
\text { age } 63 \mathrm{y} \text {, both groups }\end{array}$ & $\begin{array}{l}\text { 5-y cumulative incidence } \\
\text { of HCC in IFN group, } \\
5.9 \% \text {; in control group, } \\
17.1 \% ; P=0.045\end{array}$ & $\begin{array}{l}\text { Greater reduction in } \\
\text { risk of HCC with } \\
\text { IFN if } \alpha \text {-fetoprotein } \\
\text { declined }\end{array}$ \\
\hline Fartoux et al. [27] & $\begin{array}{l}51 \text { patients received } \\
\text { IFN- } \alpha-2 \mathrm{a}, 3 \mathrm{MU} \\
\text { TIW, for } 2 \mathrm{y} ; 51 \\
\text { patients received } \\
\text { no treatment }\end{array}$ & $\begin{array}{l}\text { Randomized trial, mean } \\
\text { age } 60 \text { y both groups }\end{array}$ & $\begin{array}{c}6 \text { patients developed } \\
\text { HCC in each group }\end{array}$ & $\begin{array}{l}\text { Primary end point was } \\
\text { composite of com- } \\
\text { plication from liver } \\
\text { disease-free survival; } \\
\text { study not powered to } \\
\text { detect difference in } \\
\text { rate of HCC }\end{array}$ \\
\hline $\begin{array}{l}\text { Di Bisceglie et al. [23], } \\
\text { Lok et al. [24•] }\end{array}$ & $\begin{array}{l}517 \text { patients received } \\
\text { pegylated IFN- } \alpha-2 \mathrm{a} \text {, } \\
90 \mu \mathrm{g} / \mathrm{wk} ; 533 \\
\text { received no treatment }\end{array}$ & $\begin{array}{l}\text { Randomized trial of } \\
\text { maintenance therapy } \\
\text { or no treatment for } 3.5 \\
\text { y, median age } 50 \text { y, } \\
\text { both groups }\end{array}$ & $\begin{array}{l}\text { After median follow-up, } \\
4.6-y \text { rate of HCC in } \\
\text { pegylated IFN group, } \\
4.5 \% \text {; in control } \\
\text { group, } 4.9 \%\end{array}$ & $\begin{array}{l}\text { In multivariate } \\
\text { analysis, age, black } \\
\text { race, alkaline phos- } \\
\text { phatase, esophageal } \\
\text { varices, smoking, } \\
\text { and platelet count } \\
\text { associated with HCC }\end{array}$ \\
\hline
\end{tabular}

\section{HCC and IFN Maintenance Therapy}

Because IFN has antifibrotic and anticarcinogenic properties, its use as maintenance therapy in patients who were nonresponders to prior treatment provided the rationale for several clinical trials (Table 1). In a randomized trial of 53 patients, Shiffman et al. [21] found that maintenance IFN, 3 million units (MU) three times a week, reduced fibrosis stage from 2.5 at baseline to 1.7 after 30 months, compared with essentially no change in fibrosis score in the group that stopped IFN. The study was not designed to detect significant differences in HCC rates between the groups. In a clinical trial that included 90 patients randomly assigned to IFN- $\alpha, 6 \mathrm{MU}$, for 12 to 24 weeks, or symptomatic treatment (control group), then observation for 2 to 7 years, two (4\%) patients in the IFN group and $17(38 \%)$ patients in the control group developed HCC $(P=0.002)$ [22]. Data from these studies provided the rationale to consider prescribing IFN maintenance therapy in patients with hepatitis C and advanced fibrosis who were nonresponders.

The Hepatitis C Antiviral Long-Term Treatment Against Cirrhosis (HALT-C) trial was designed to determine if long-term treatment with pegylated IFN reduces progression of liver disease as indicated by death, hepatocellular carcinoma, hepatic decompensation, or progression to cirrhosis in patients with bridging fibrosis [23]. In HALT-C, 1050 patients with bridging fibrosis or cirrhosis who had not responded to previous therapy with pegylated IFN and ribavirin were randomly assigned to subcutaneous pegylated IFN- $\alpha-2 \mathrm{a}, 90 \mu \mathrm{g} / \mathrm{wk}$, or no treatment. More than $90 \%$ of the patients were genotype 1 and the average age was 50 years in each group. At 3.5 years after randomization, 12 patients in the pegylated IFN group and 15 patients in the control group developed HCC $(P=$ NS). No differences were seen in HCC rates when results were stratified by the presence or absence of cirrhosis. A subsequent analysis from HALT-C on the effect of pegylated-IFN maintenance therapy on HCC in patients with hepatitis $\mathrm{C}$ and bridging fibrosis or cirrhosis was conducted in 1005 patients; the annual incidence for HCC was $1.1 \%$ in the cohort [24•]. During a median follow-up of 4.5 years, the cumulative 5 -year incidence of HCC was $5.4 \%$ for treated patients and $5.0 \%$ for controls $(P=0.78)$. The cumulative 5 -year incidence was higher among patients with cirrhosis $(7.0 \%)$ than in those with bridging fibrosis $(4.1 \%)(P=0.08)$. The rate of HCC in patients without cirrhosis was unexpected. Significant predictors for developing HCC were older age, black race, esophageal varices, low platelet count, and history of ever smoking. 
Smaller studies suggest certain groups of patients may benefit from maintenance therapy. In a study of 125 patients 60 years of age and older with chronic hepatitis $\mathrm{C}$ treated with IFN- $\alpha, 3 \mathrm{MU}$, two to three times weekly, for a mean of 2.5 years, investigators compared rates of HCC with rates among 240 patients treated with herbal medicines [25]. The 5-year cumulative rate of HCC was $5.9 \%$ in the IFN group and $13.7 \%$ in the herbal group [25]. The authors suggest that older patients with advanced fibrosis may benefit from prolonged IFN therapy. It is interesting that in individuals with hepatitis $C$ who receive IFN therapy, $\alpha$-fetoprotein (AFP) levels decline regardless of virologic response [26]. In a retrospective analysis of patients with chronic hepatitis $\mathrm{C}$ who underwent IFN-based therapy, AFP levels decreased by $57 \%$. Patients with AFP levels greater than $10 \mathrm{ng} / \mathrm{mL}$ at end of treatment were more likely to develop HCC $(P=0.021)$ [26]. A trial of 2 years' duration that included 102 cirrhotic patients with hepatitis $\mathrm{C}$ who were randomly assigned to IFN- $\alpha-2$ a or no therapy reported no difference in HCC rates between the two groups [27].

The current evidence does not support the routine use of IFN maintenance therapy to reduce the risk of HCC in hepatitis $\mathrm{C}$ patients who are prior treatment failures. However, future studies could evaluate the association between IFN maintenance therapy and risk of HCC in subgroups of patients who appear at particularly high risk for HCC or who have characteristics of a positive response, including patients with a $2-\log$ or greater reduction in viral load, or a reduction in necroinflammation and/or fibrosis on liver biopsy.

\section{IFN as a Chemotherapeutic Agent for HCC}

IFN- $\alpha$ is prescribed as a chemotherapeutic agent to treat malignant melanoma and hematologic malignancies (eg, hairy cell leukemia). IFN has been studied in trials for treating patients with HCC, but many studies included patients with predominantly hepatitis B $[28,29]$. The largest randomized clinical trial of patients with hepatitis C and HCC who were treated with IFN did not demonstrate a benefit with therapy [30]. In this trial, 58 patients were randomly assigned to IFN- $\alpha-2 b, 3 \mathrm{MU}$, three times a week for 1 year, or symptomatic treatment. Partial tumor response and tumor progression were not significantly different between the two groups. Overall survival was $58 \%$ in the IFN group and $38 \%$ in the control group $(P=0.19)$. Possibly, the study did not show significant benefit because the sample size may have been too small, because it was powered to detect a $30 \%$ improvement in overall survival. Also, patients in this trial had advanced HCC, and it may be that IFN benefits patients with earlier stage disease. IFN therapy was poorly tolerated, with $48 \%$ of patients discontinuing treatment. Based on these data, IFN cannot be recommended for treatment of HCC outside a clinical trial.

\section{IFN After Liver Resection or Ablation to Prevent or Treat Recurrent HCC}

IFN was studied as adjuvant therapy after liver resection or ablation of hepatocellular carcinoma in patients with hepatitis $\mathrm{C}$ cirrhosis because of its anticarcinogenic properties (Table 2) [31-37]. Among 209 patients with hepatitis $\mathrm{C}$ who underwent curative resection for HCC, 70 patients received IFN therapy [31]. Three-year tumorfree survival rates were higher among 40 patients who achieved SVR or biochemical response, compared with the untreated group $(71 \%$ vs $46 \% ; P<0.001)$. Patients with a single tumor derived the most benefit from IFN therapy. In a randomized clinical trial, 150 patients with hepatitis C and HCC (of whom 80 were hepatitis B core antibody negative and 70 were hepatitis B core antibody positive) were randomly assigned within 6 weeks after liver resection to IFN, $3 \mathrm{MU}$ three times weekly for 48 weeks, or an untreated control group [32•]. In the overall study group, no significant differences in HCC recurrence rates existed between the treated and control groups after liver resection. The subgroup of patients who derived a benefit from postresection treatment with IFN were those hepatitis C patients who were hepatitis B core antibody negative; the risk of HCC recurrence 2 years or later after resection was reduced by $70 \%$ (HR, 0.3; 95\% CI, $0.09-$ $0.9 ; P=0.048)$. Compared with patients with hepatitis $C$ who have not had hepatitis $B$, patients with hepatitis $C$ and prior hepatitis $\mathrm{B}$ infection may be at increased risk for HCC, because hepatitis B may promote carcinogenesis through mechanisms independent of HCV. Patients with single HCCs less than $3 \mathrm{~cm}$ without vascular invasion who were treated with IFN were less likely to develop recurrent HCC compared with the control group (HR, $0.4 ; 95 \%$ CI, 0.19-0.89; $P=0.02$ ).

Investigators tested the efficacy of IFN- $\alpha$ combined with 5 -fluorouracil (5-FU) in 30 patients with advanced HCC and tumor thrombi in the main portal vein after resection [33]. Patients received subcutaneous IFN- $\alpha, 5 \mathrm{MU}$, three times weekly, postoperatively for a total dose of 60 MU. 5FU at a dose of $300 \mathrm{mg} / \mathrm{m}^{2}$ was administered through the proper hepatic artery during the first and second postoperative weeks. The primary outcome was a complete response defined as normalization of tumor marker levels and disappearance of all tumors and portal vein thromboses on CT or MRI. A partial response was defined as a decrease in tumor marker levels and a decrease in tumor size between $50 \%$ and $99 \%$ of the original size. The average tumor size was $16 \mathrm{~mm}$. Six $(20 \%)$ patients had a complete response, 4 (13\%) patients had a partial response, and $19(63 \%)$ patients had progressive disease. The median overall survival was 9.5 months, and 3 -year survival rate was $21 \%$. The median survival was 29 months in patients with a complete or partial response and 6 months in patients with disease progression or no changes. The median overall survival was 16 months for patients whose tumors stained IFN type 2 receptor (IFNAR2)-positive and 5.5 months for patients whose tumors stained IFNAR2-negative $(P<0.0025)$. Although 


\begin{tabular}{|c|c|c|c|c|}
\hline Study & Treatment groups, $n$ & Design & Results & Comments \\
\hline $\begin{array}{l}\text { Mazzaferro et al. } \\
{[32 \bullet]}\end{array}$ & $\begin{array}{l}76 \text { patients received IFN } \\
\text { within } 6 \text { wk of surgery; } \\
74 \text { did not receive IFN }\end{array}$ & $\begin{array}{l}\text { Randomized trial of } \\
\text { IFN- } \alpha, 3 \mathrm{MU} \text { TIW } \\
\text { for } 48 \text { wk, or no IFN, } \\
\text { after resection }\end{array}$ & $\begin{array}{l}\text { No significant } \\
\text { difference in recur- } \\
\text { rence-free survival } \\
\text { between two groups; } \\
42.8 \% \text { IFN group vs } \\
37.1 \% \text { control group }\end{array}$ & $\begin{array}{l}\text { Trend to lower recurrence } \\
\text { after } 2 \text { y in patients with } \\
\mathrm{HCV} \text { who were } \mathrm{HBcAb} \\
\text { negative, } 42.6 \% \text { in IFN } \\
\text { group vs } 29.9 \% \text { in control } \\
\text { group; } P=0.24\end{array}$ \\
\hline Ikeda et al. [35] & $\begin{array}{l}10 \text { patients received } \\
\text { IFN- } \beta ; 10 \text { patients } \\
\text { received no IFN }\end{array}$ & $\begin{array}{l}\text { Randomized trial of } \\
\text { IFN- } \beta, 6 \mathrm{MU} \text { twice } \\
\text { weekly, for } 36 \text { mo } \\
\text { after resection or } \\
\text { ablation vs no post- } \\
\text { treatment IFN }\end{array}$ & $\begin{array}{l}\text { Over median follow- } \\
\text { up of } 25 \text { mo, tumor } \\
\text { recurrence rate in IFN } \\
\text { group was } 10 \% \text {, and } \\
\text { in control group was } \\
70 \% ; P=0.02\end{array}$ & $\begin{array}{l}80 \% \text { of patients in each } \\
\text { group underwent } \\
\text { resection and } 20 \% \text { in } \\
\text { each group had ethanol } \\
\text { injection, } 90 \% \text { in each } \\
\text { group had } 1 \text { tumor }\end{array}$ \\
\hline Shiratori et al. [36] & $\begin{array}{l}49 \text { patients received } \\
\text { IFN after ethanol } \\
\text { ablation; } 25 \text { controls } \\
\text { received no treatment } \\
\text { after ethanol ablation }\end{array}$ & $\begin{array}{l}\text { Randomized trial of } \\
\text { IFN, } 6 \text { MU TIW, } \\
\text { for } 48 \mathrm{wk}\end{array}$ & $\begin{array}{l}\text { No difference in recur- } \\
\text { rence rates; survival } \\
\text { at } 5 \text { y with IFN was } \\
68 \% \text {, and without } \\
\text { IFN was } 48 \% ; P \\
\text { value not reported }\end{array}$ & $\begin{array}{l}\text { All patients had } 3 \text { or fewer } \\
\text { tumors and viral load }<2 \\
\text { million copies } / \mathrm{mL}\end{array}$ \\
\hline Kubo et al. [39] & $\begin{array}{l}15 \text { patients received } \\
\text { IFN 5-15 wk after } \\
\text { resection; } 15 \text { patients } \\
\text { received no IFN }\end{array}$ & $\begin{array}{l}\text { Randomized trial of } \\
\text { IFN, } 6 \mathrm{MU} \text { IM daily } \\
\text { for } 2 \mathrm{wk} \text {, then TIW } \\
\text { for } 14 \mathrm{wk} \text {, then twice } \\
\text { weekly for } 88 \mathrm{wk}\end{array}$ & $\begin{array}{l}\text { Overall survival at } 4 \text { y } \\
\sim 85 \% \text { in IFN group } \\
\text { and } \sim 40 \% \text { in control } \\
\text { group; } P=0.041\end{array}$ & $\begin{array}{l}\text { In patients with recurrence, } \\
\text { control group had more } \\
\text { tumors compared with } \\
\text { IFN group }\end{array}$ \\
\hline
\end{tabular}

this study has several limitations (lack of a control group; underlying etiology of liver disease not supplied), it provides ideas for future studies. The identification of IFNAR2 as a potential prognostic indicator of therapeutic efficacy of IFN is an interesting finding that should be explored.

Others evaluated IFN in combination with traditional chemotherapies after liver resection. Eighty-six patients with HCC and tumor thrombi in the main portal vein or branches were divided into two groups who underwent resection [34]. One group received 5-FU, doxorubicin, cisplatin, and IFN- $\alpha$ after resection and thrombectomy, and the second group underwent resection and thrombectomy only. In the group that received chemotherapy, median tumor-free survival was 5.1 months and overall survival was 2.5 months $(P=0.017)$; in the group that underwent resection only, median tumor-free survival was 11.5 months and overall survival was 6.2 months $(P=0.007)$. In multivariate analyses, chemotherapy along with pathologic grading and tumor size were independent prognostic factors of tumor-free survival.

The author of a meta-analysis suggested that IFN therapy appears effective after curative treatment for HCC in hepatitis $\mathrm{C}$ patients because of improved survival and lower recurrence rates [38]. However, the author cautions that routine use of IFN cannot be advocated based on the available evidence because the studies included in the analysis were heterogenous, and in some cases benefits of IFN were only demonstrated in subgroup analyses. Some studies included patients with early HCC, whereas other investigators evaluated patients with more advanced cancer. Moreover, some studies included patients with hepatitis C, whereas others included patients with hepatitis $\mathrm{B}$ or both hepatitis B and C. Patients with hepatitis B and HCC may not be comparable to patients with HCV and HCC because those with hepatitis B may develop HCC in the absence of advanced fibrosis, and thus are more likely to be resection candidates. Studies have compared IFN alone or in combination with other chemotherapeutic agents. Given the foregoing, a reasonable approach is to consider pegylated IFN with ribavirin after resection or ablation in patients who can tolerate therapy and who do not have decompensated cirrhosis with the goal of achieving SVR.

\section{Conclusions}

The risk of HCC is substantially reduced in patients who achieve SVR after IFN-based therapy; however, the risk is not completely eliminated and patients with advanced cirrhosis should continue surveillance for HCC. Although the HALT-C trial provides compelling evidence against the routine use of IFN maintenance therapy in patients with hepatitis $\mathrm{C}$ and bridging fibrosis or cirrhosis, data from other clinical trials suggest a subgroup of patients may benefit. A clinical trial of IFN maintenance therapy may be warranted in older patients (> 55-60 years) who have a 2-log drop in viral load during the first 12 weeks, and reduced necroinflammation on follow-up liver biopsy. The data do not support the routine use of IFN after resection 
or ablation in patients with hepatitis C and HCC. Certainly, patients who are otherwise treatment candidates should be considered for antiviral therapy with the goal of achieving SVR. With the development of sorafenib, future studies could examine the combination of sorafenib with IFN for treatment of HCC, or the role of IFN in preventing or slowing tumor progression after radiofrequency/microwave ablation or chemoembolization.

\section{Disclosure}

No potential conflict of interest relevant to this article was reported.

\section{References and Recommended Reading}

Papers of particular interest, published recently, have been highlighted as:

- Of importance

$\bullet \quad$ Of major importance

1. Llovet JM, Ricci S, Mazzaferro V, et al.: Sorafenib in advanced hepatocellular carcinoma. New Engl J Med 2008, 359:378-390.

2. El-Serag H, Rudolph L: Hepatocellular carcinoma: epidemiology and molecular carcinogenesis. Gastroenterology 2007, 132:2557-2576.

3. Hino O: Understanding hypercarcinogenic state in chronic hepatitis: a clue to the prevention of human hepatocellular carcinoma. J Gastroenterol 2002, 37:883-887.

4. Matsuzaki K, Murata M, Yoshida K, et al.: Chronic inflammation associated with hepatitis $\mathrm{C}$ virus infection perturbs hepatic transforming growth factor signaling promoting cirrhosis and hepatocellular carcinoma. Hepatology 2007, 46:48-57.

5. Schulze-Krebs A, Preimel D, Popov Y, et al.: Hepatitis C virus-replicating hepatocytes induce fibrogenic activation of hepatic stellate cells. Gastroenterology 2005, 129:246-248.

6. Moriye K, Fujiie H, Shintani Y, et al.: The core protein of hepatitis $\mathrm{C}$ virus induces hepatocellular carcinoma in transgenic mice. Nat Med 1998, 4:1065-1067.

7. Khan F, Peltekian KM, Peterson TC: Effect of interferonalpha, ribavirin, pentoxyfylline, and interleukin-18 antibody on hepatitis C sera-stimulated hepatic stellate cell proliferation. J Interferon Cytokine Res 2008, 28:643-651.

8. Tasci I, Mas MR, Vural SR, et al.: Rat liver fibrosis regresses better with pegylated interferon alpha-2b and ursodeoxycholic acid treatments than spontaneous recovery. Liver Int 2006, 26:261-268.

9. Wang L, Wu WZ, Sun HC, et al.: Mechanism of interferon alpha on inhibition of metastasis and angiogenesis of hepatocellular carcinoma after curative resection in nude mice. J Gastrointest Surg 2003, 7:587-594.

10. Cao B, Chen XP, Zhu P, et al.: Inhibitory effect of interferon-alpha- $2 b$ on expression of cyclooxygenase- 2 and vascular endothelial growth factor in human hepatocellular carcinoma inoculated nude mice. World J Gastroenterol 2008, 14:6802-6807.

11. Nakamura M, Nagano H, Sakon M, et al.: Role of the Fas/ FasL pathway in combination therapy with interferon-alpha and fluorouracil against hepatocellular carcinoma in vitro. J Hepatol 2007, 46:77-88.

12. Papatheodoridis GV, Papadimitropoulos VC, Hadziyannis SJ: Effect of interferon therapy on the development of hepatocellular carcinoma in patients with hepatitis $\mathrm{C}$ virus-related cirrhosis: a meta-analysis. Aliment Pharmacol Ther 2001, 15:689-698.
13. MacParland SA, Pham TNQ, Guy CS, Michalak TI: Hepatitis $\mathrm{C}$ virus persisting after clinically apparent sustained virological response to antiviral therapy retains infectivity in vitro. Hepatology 2009, 49:1431-1441.

14. Hayashi T, Tamori A, Nishikawa M, et al.: Differences in molecular alterations of hepatocellular carcinoma between patients with a sustained viral response and those with hepatitis C virus infection. Liver Int 2009, 29:126-132.

15. Veldt BJ, Heathcote EJ, Wedemeyer H, et al.: Sustained virologic response and clinical outcomes in patients with chronic hepatitis $\mathrm{C}$ and advanced fibrosis. Ann Intern Med 2007, 147:677-684.

16. Kobayashi S, Takeda T, Enomoto M, et al.: Development of hepatocellular carcinoma in patients with chronic hepatitis $\mathrm{C}$ who had a sustained virological response to interferon therapy: a multicenter, retrospective cohort study of $\mathbf{1 1 2 4}$ patients. Liver Int 2007, 27:186-191.

17. Ikeda K, Saitoh S, Arase Y, et al.: Effect of interferon therapy on hepatocellular carcinogenesis in patients with chronic hepatitis C: A long-term observation study of 1,643 patients using statistical bias correction with proportional hazard analysis. Hepatology 1999, 29:1124-1130.

18. Yoshida H, Shiratori Y, Moriyama M, et al.: Interferon therapy reduces the risk for hepatocellular carcinoma: national surveillance program of cirrhotic and noncirrhotic patients with chronic hepatitis C in Japan. Ann Intern Med 1999, 131:174-181.

19. Imai Y, Kawata S, Tamura S, et al.: Relation of interferon therapy and hepatocellular carcinoma in patients with chronic hepatitis C. Ann Intern Med 1998, 129:94-99.

20. Sanefuji K, Kayashima H, Iguchi T, et al.: Characterization of hepatocellular carcinoma developed after achieving sustained virological response to interferon therapy for hepatitis C. J Surg Oncol 2009, 99:32-37.

21. Shiffman ML, Hofmann CM, Contos MJ, et al.: A randomized, controlled trial of maintenance interferon for patients with chronic hepatitis $\mathrm{C}$ virus and persistent viremia. Gastroenterology 1999, 117:1164-1172.

22. Nishiguchi S, Kuroki T, Nakatani S, et al.: Randomised trial of effects of interferon-alpha on incidence of hepatocellular carcinoma in chronic active hepatitis $\mathrm{C}$ with cirrhosis. Lancet 1995, 346:1051-1055.

23. Di Bisceglie AM, Shiffman ML, Everson GT, et al.: Prolonged therapy of advanced chronic hepatitis $\mathrm{C}$ with lowdose peginterferon. N Engl J Med 2008, 359:2429-2441.

24. Lok AS, Seeff LB, Morgan TR, et al.: Incidence of hepatocellular carcinoma and associated risk factors in hepatitis C-related advanced liver disease. Gastroenterology 2009, 136:138-148.

This article presents a detailed analysis from the HALT-C trial on risk of HCC in maintenance IFN and control groups. No significant difference in rate of HCC was found between the two groups.

25. Arase Y, Ikeda K, Suzuki F, et al.: Prolonged-interferon therapy reduces hepatocarcinogenesis in aged patients with chronic hepatitis C. J Med Virol 2007, 79:1095-1102.

26. Tamura Y, Tamagiwa S, Aoki Y, et al.: Serum alpha-fetoprotein levels during and after interferon therapy and the development of hepatocellular carcinoma in patients with chronic hepatitis C. Dig Dis Sci 2008 (Epub ahead of print).

27. Fartoux L, Degos F, Trepo C, et al.: Effect of prolonged interferon therapy on the outcome of hepatitis $\mathrm{C}$ virusrelated cirrhosis:a randomized trial. Clin Gastroenterol Hepatol 2007, 5:502-507.

28. Patt YZ, Yoffe B, Charnsangavej C, et al.: Low serum alpha-fetoprotein level in patients with hepatocellular carcinoma as a predictor of response to 5 -FU and interferon-alpha-2b. Cancer 1993, 72:2574-2582.

29. Lai CL, Lau JYN, Wu PC, et al.: Recombinant interferon alpha in inoperable hepatocellular carcinoma: a randomized controlled trial. Hepatology 1993, 17:389-394.

30. Llovet JM, Sala M, Castells L, et al.: Randomized controlled trial of interferon treatment for advanced hepatocellular carcinoma. Hepatology 2000, 31:54-58. 
31. Uenishi T, Nishiguchi S, Tanaka S, et al.: Response to interferon therapy affects risk factors for postoperative recurrence of hepatitis $C$ virus-related hepatocellular carcinoma. J Surg Oncol 2008, 98:358-362.

32.- Mazzaferro V, Romito R, Schiavo M, et al.: Prevention of hepatocellular carcinoma recurrence with alpha-interferon after liver resection in HCV cirrhosis. Hepatology 2006, 44:1543-1554

This randomized study of IFN after resection of HCC in HCV cirrhotic patients demonstrated no overall benefit with IFN. The subgroup of hepatitis $C$ patients who were hepatitis B core antibody negative and were treated with IFN had lower recurrence rates.

33. Nagano H, Miyamoto A, Wada H, et al.: Interferon-alfa and 5-fluorouracil combination therapy after palliative hepatic resection in patients with advanced hepatocellular carcinoma, portal venous tumor thrombus in the major trunk and multiple nodules. Cancer 2007, 110:2493-2501.

34. Liang LJ, Hu WJ, Yin XY, et al.: Adjuvant intraportal venous chemotherapy for patients with hepatocellular carcinoma and portal vein tumor thrombi following hepatectomy plus portal thrombectomy. World J Surg 2008, 32:627-631.
35. Ikeda K, Arase Y, Saitoh S, et al.: Interferon beta prevents recurrence of hepatocellular carcinoma after complete resection or ablation of the primary tumor: a prospective randomized study of hepatitis $\mathrm{C}$ virus-related liver cancer. Hepatology 2000, 32:228-232.

36. Shiratori Y, Shiina S, Teratani, et al.: Interferon therapy after tumor ablation improves prognosis in patients with hepatocellular carcinoma associated with hepatitis $C$ virus. Ann Intern Med 2003, 138:299-306.

37. Jeong S, Aikata H, Katamura Y, et al.: Low-dose intermittent interferon-alpha therapy for HCV-related liver cirrhosis after curative treatment of hepatocellular carcinoma. World J Gastroenterol 2007, 13:5188-5195.

38. Kudo M: Impact of interferon therapy after curative treatment of hepatocellular carcinoma. Oncology 2008, 75(Suppl 1):30-41.

39. Kubo S, Nishiguchi S, Hirohashi K, et al.: Randomized clinical trial of long-term outcome after resection of hepatitis $C$ virus-related hepatocellular carcinoma by postoperative interferon therapy. Br J Surg 2002, 89:418-422. 
